\title{
Seasonal Variations in Certain Hematological Factors of Catla Catla (Hamilton 1822)
}

\author{
${ }^{1}$ Binod Bihari Patra, ${ }^{2}$ Rama Prasad Panda, ${ }^{3}$ Ajay Kumar Patra \\ ${ }^{1}$ Dept. Physics, Hinjilicut,Science College GM, Odisha \\ ${ }^{2}$ HOD Zoology, Anchalik Science College Khetryaberhampur, GM, Odisha \\ ${ }^{3}$ Visiting Prof., Dept. of Zoology Utkal University Odisha
}

\begin{abstract}
Hematological parameters are repeatedly used as an essential tool to assess the health condition of fish. The purpose of this study was to assess the reference values of some hematological parameters of Catla, catla catla collected from fresh water pond in a tropical climate of India from July 2011 to 2013. Variation in hematological parameters such as hemoglobin, erythrocyte count, total leucocytes count, hematocrit, mean corpuscular volume (MCV) and mean corpuscular hemoglobin concentration (MCHC) of fish were compared according to sex and seasonal differences. Analysis of variance showed that there were significant differences between sexes and the results indicated that the blood parameter levels between the sexes in summer were significantly different than that measure in other seasons except mean corpuscular hemoglobin(MCH) and $(M C H C)$ value $(P<0.05)$. The number of total leukocyte levels was found to be higher in female fish especially in breeding seasons, but the levels of hemoglobin, hematocrit and MCV values were high in male fish in an annual period. However, there was no difference in $\mathrm{MCH}$ and $M C H C$ values between the sexes and seasons throughout the study period. These may be related to the seasons of sampling and changing physiological cycles during these months. The correlation between measured hematological parameters was also determined.
\end{abstract}

Key words: Seasonal Variations- Hematology-Catla catla Reference Values

\section{Introduction}

Hematological parameters are frequently used as an essential diagnostic tool to assess the health condition of lower vertebrates due to the increasing emphasis on pisciculture and greater awareness of population of natural water resources (Bhaskar and Rao 1985). There are several publications, reports on hematological aspects of the vertebrate species in order to correlate their physiology and evolution, but a break through knowledge of fish physiology is becoming more imperative due to diagnostic evolution, economic importance and comparative study of fish. In recent years, blood parameters have been commonly used to observe and follow the quality of fish (Bhaskar and Rao 1985). One of the difficulties in assessing the state of propagation has been the paucity of reliable references under natural habitat. In pursuant to this objective, many fish physiologists have concentrated to hematological studies probably because it has proved a valuable diagnostic tool in evaluating fish quality. (Hesser1960; Anderson and Klontz 1965; Kori-Siakpre et al. 2005; Oluyemi et al, 2008).

A major part of the world's food is being supplied from fishery sources, thus it is essential to secure the propagation of fishes ( Tripathy and Harsh 2002). First of all, the analysis of hematological parameters is one of the most valuable modern diagnostic tools to understand fish health. Recently, Anver(2004) established that the physiological values of hematological parameters are species specific and age dependent. Many publications reported by different workers that qualitative and quantitative variations in hematological parameters including the red blood corpuscles (RBC) and white blood corpuscles (WBC) numbers, cell proportions of leukocyte, the amount of hemoglobin and the size of WBC and RBC are the most significant findings as regards diagnosis. Hematocrit, erythrocytes count and hemoglobin concentrations are the most readily determined hematological parameters under the field and hatchery conditions (Bhaskar and Rao 1990). Among different hematological parameters, hematocrit value is not easily altered as other parameters and should be used in conjunction with erythrocyte and leucocytes count, hemoglobin content osmotic fragility, and differential leucocytes count (Wedemeyer et. al 1983). Most of the several contributions towards a better understanding of fish hematology deal with marine species ( Johnson 1968). Variation in hematological parameters of fishes are caused by environmental stress (Hickey 1982), malnutrition ( Casillas and Smith 1977 ), gender ( Siddique and Naseem 1979 ; Collazos et al. 1998 ), fish size ( Garcia et al. 1992 ), seasonal differences and breeding efficiency ( Cech and Wohlschlang 1981 ). The environmental influence on blood parameters of fishes has generally been used as an effective and sensitive index to monitor the physiological and pathological changes in fish (Iwama et al. 1976; Chakrabarti and Banarjee 1988; Orun et al. 2003 ). Interestingly, the hematology of fish continues to offer valuable diagnostic tool and progress in establishing normal range values for blood parameters of different fish species, but the information regarding Cyprinidae species is incomplete. This study was undertaken to establish 
reference values for some hematological parameters of a fresh water fish Catla catla living in wild on the basis of sex and seasons.

\section{Material and methods}

\section{Study site and animal sample collection}

C.catla is fresh water teleost belonging to the family Cyprinide and is high-quality flesh together with its good taste made it a high-priced fish in the local market in India. For the present study, fish samples were collected monthly from a fresh pond of Khurda District, Bhubaneswar, India $\left(19^{0} 40^{\prime \prime} \mathrm{N}\right.$ to $20^{\circ} 25^{\prime \prime} \mathrm{N}$ Latitude and $24^{\circ} 55^{\prime \prime} \mathrm{E}$ to $36^{\circ} 0.5^{\prime \prime}$ E Longitude; area, $2889 \mathrm{~km}^{2}$ ) during July 2011 to June 2013 . This area and pond was chosen considering tropical climate, average ambit temperature range between $9.5^{\circ} \mathrm{C}$ (winter) to $41.4^{0} \mathrm{C}$ (summer), with annual rain fall of $1,449.1 \mathrm{~mm}$, agricultural, domestic fish farming and human activities. Fifteen to twenty individuals $(33.5 \pm 3.0 \mathrm{~cm}$ in standard length and $1,100 \pm 75 \mathrm{gm}$ in weight) wre selected in each month from the pond using extension net. Fish samples were put into transport tanks (300L) filled with pond water and transported to the laboratory on the same day. During transport water tank was oxygenated properly.

\section{Blood sample collection}

Blood sample were obtained from caudal peduncle and heart by cardiac puncture using disposable plastic syringes fitted with 26-gage needle that was already moistured with heparin and expelled into separate heparinised vials immediately on ice ( Orun et al. 2003, Lavanya et al. 2011). For the estimation of hemoglobin, RBCs and WBCs count, we used whole blood.

\section{Hematological analysis}

Cynmethaemoblobin method was used for evolution of hemoglobin concentration as described by Lavanya et al. (2011). For counting the number of RBCs and WBCs, we followed standard procedure as published earlier by us ( Pal et al. 2008, Parida et al. 2011). The results were expressed as the number of RBC or WBC per $1 \mathrm{~mm}^{3}$ of blood. We counted in an improved Neubauer hemocytometer using Hayem's diluting fluid the total red blood corpuscle or erythrocyte. The number of cells count was determined as described Svobodova et al. (1991) and Oluyemi et al. (2008). The total $\mathrm{RBC}$ count per $\mathrm{mm}^{3}=200 \times 50 \times \mathrm{N}=10,000 \mathrm{~N}(\mathrm{~N}=$ number of $\mathrm{RBc}$ counted, dilution factor $=200$ ). The total WBC or leucocyte was counted in an improved Neubauer hemocytometer using Tuke's diluting fluid. The total count per cubic $\mathrm{mm}$ was obtained as $20 \mathrm{x} 1 \mathrm{xL} / 0.4 \mathrm{cells}=50$ $x \mathrm{~L}(\mathrm{~L}=$ Number of $\mathrm{WBC}$ counted dilution factor $=50)$. The determination of packed cell volume $(\mathrm{PCV})$ was performed as published by Adehayo et al. (2007). The PCV was estimated by using micro-hemotocrit reader and expressed in percentage. Erythocyte indices mean corpuscular volume (MCV), mean corpuscular hemoglobin $(\mathrm{MCH})$ and mean corpuscular hemoglobin concentration $(\mathrm{MCHC})$ were calculated as per formulae of Dacie and Lewis (1975).

$\mathrm{MCV}=\mathrm{PCV} \times 100 /$ erythrocyte count

$\mathrm{MCH}=$ hemoglobin $\mathrm{x} 10 /$ erythrocyte count

MCHC=hemoglobin x 100/PCV

\section{Statistical analysis}

Hematological data resulting from the experiment were subjected to one-way analysis of variance (ANOVA) by using the SPSS 17 for windows. Differences between means was determined by Duncan multiple range test $(\mathrm{p}<0.05)$. The correlation between hematological variables was analyzed by Pearson coefficient for linear correlation (r) at $\mathrm{p}<0.05$.

\section{Hematological analysis}

\section{Result}

In order to determine the hematological parameters of each adult fish, sex seasonal variations were considered during the two years of our study period. The average data of the hematological parameters such as $\mathrm{RBC}, \mathrm{WBC}$, hemoglobin, hematocrit, MCV, MCH and MCHC were depicted for both the sexes in different seasons (Table-1). As shown in Table-2 there were significant differences (ANOVA) in hematological parameters between sexes and seasons. The correlations between hematological parameters regarding seasons and sexes has been illustrated in Table-3, 4 and 5 . 


\section{Hemoglobin content}

Hemoglobin content of C.catla oscillated between 5.0 and $7.775 \mathrm{~g} / \mathrm{dl}$ during different seasons (Table1). In male hemoglobin $(\mathrm{Hb})$, concentration varied from 5.4 to $8.45 \mathrm{~g} / \mathrm{dl}$ with annual mean of $6.97 \pm 0.30 \mathrm{~g} / \mathrm{dl}$. In the female specimen, value was within the range of 4.6-7.1 g/dl with annual mean of 5.90 $\pm 0.25 \mathrm{~g} / \mathrm{dl}$. The higher concentration of $\mathrm{Hb}$ in both the sexes was obtained in summer and lower value in the autumn season (Fig. 1). There are significant differences between sexes.

\section{Total erythrocyte count}

The total number of erythrocyte ranged from $1.36 \times 10^{6}$ to $1.77 \times 10^{6} / \mathrm{mm}^{3}$ blood in male fish and 1.15 x $10^{6}$ to $1.69 \times 10^{6} / \mathrm{mm}^{3}$ blood during annual study period (Table-1). Male possessed higher number of RBC than that of female, where as higher value was noted in summer and lower in winter in both the sexes (Fig-2). The annual average of RBC in male and female was $1.644 \times 10^{6}$ and $1.44 \times 10^{6} / \mathrm{mm}^{3}$ blood, respectively.

\section{Total leukocyte count (TLC)}

Season-wise total leukocyte count (TLC) value was higher in summer and lower in the winter in bothj sex C.catla. TLC varied between $2.7 \times 10^{3}-5.12 \times 10^{3} / \mathrm{mm}^{3}$ of blood and $3.00 \times 10^{3}-5.6 \times 10^{3 \mathrm{~g} /} \mathrm{mm}^{3}$ of blood in male and female fish, respectively (Table-1). The annual mean value of male and female fish was $3.754 \times 10^{3}$ and $4.124 \times 10^{3} / \mathrm{mm}^{3}$ of blood, respectively. Thus female fish had higher values than that of male fish.

Table-1 Seasonal variations in blood parameters of male and female C.catla

\begin{tabular}{|c|c|c|c|c|c|c|c|c|c|}
\hline Season & Sex & & Hemo & $\mathrm{RBC}$ & Leuco & Hemato & $\mathrm{MCV}$ & $\mathrm{MCHC}$ & $\mathrm{MCH}$ \\
\hline \multirow[t]{4}{*}{ Spring } & \multirow[t]{2}{*}{ Male } & Mean & 7.4100 & 1.7100 & 3.9000 & 31.4900 & 172.1000 & 31.6000 & 55.3100 \\
\hline & & SE & $0.16743 c$ & $0.01155 b$ & $0.10392 b$ & $0.14434 \mathrm{c}$ & $3.23316 \mathrm{a}$ & $0.14434 b$ & $0.28868 \mathrm{c}$ \\
\hline & \multirow[t]{2}{*}{ Female } & Mean & 6.5000 & 1.5300 & 4.5000 & 26.3000 & 171.4000 & 31.4000 & 57.0000 \\
\hline & & SE & $0.13856 \mathrm{~b}$ & $0.02309 \mathrm{c}$ & $0.12702 b$ & $0.24249 \mathrm{~d}$ & $2.07816 \mathrm{a}$ & $0.11547 \mathrm{a}$ & $0.20207 \mathrm{~d}$ \\
\hline \multirow[t]{4}{*}{ Summer } & \multirow[t]{2}{*}{ Male } & Mean & 8.4500 & 1.7700 & 5.1200 & 32.9000 & 179.9000 & 31.1500 & 54.0000 \\
\hline & & SE & $0.21362 \mathrm{~d}$ & $0.02887 \mathrm{~d}$ & $0.30022 \mathrm{c}$ & $0.17321 \mathrm{~d}$ & $2.51147 \mathrm{a}$ & $0.24249 b$ & $0.20267 \mathrm{~b}$ \\
\hline & \multirow[t]{2}{*}{ Female } & Mean & 7.1000 & 1.6900 & 5.6100 & 27.0000 & 179.0000 & 31.5500 & 55.2000 \\
\hline & & SE & $0.16166 \mathrm{c}$ & $0.01732 \mathrm{~d}$ & $0.36188 \mathrm{c}$ & $0.14434 d$ & $1.87639 \mathrm{a}$ & $0.28868 b$ & $0.25981 \mathrm{c}$ \\
\hline \multirow[t]{4}{*}{ Rainy } & \multirow[t]{2}{*}{ Male } & Mean & 7.2000 & 1.7000 & 4.6500 & 31.0000 & 175.7900 & 31.8000 & 53.9000 \\
\hline & & $\mathrm{SE}$ & $0.11547 \mathrm{c}$ & $0.02021 b$ & $0.25981 b$ & $0.11547 \mathrm{c}$ & $3.03109 \mathrm{a}$ & $0.38682 b$ & $0.12702 b$ \\
\hline & \multirow[t]{2}{*}{ Female } & Mean & 6.3000 & 1.5800 & 4.4100 & 24.9000 & 175.5000 & 32.2000 & 54.0100 \\
\hline & & $\mathrm{SE}$ & $0.08660 \mathrm{~b}$ & $0.01443 c$ & $0.14434 b$ & $0.19630 \mathrm{c}$ & $3.75278 \mathrm{a}$ & $0.28868 b$ & $0.17321 b$ \\
\hline \multirow[t]{4}{*}{ Autumn } & \multirow[t]{2}{*}{ Male } & Mean & 6.4000 & 1.7000 & 3.0000 & 27.8000 & 172.9000 & 31.0000 & 53.0000 \\
\hline & & SE & $0.14434 b$ & $0.01443 b$ & $0.08660 \mathrm{a}$ & $0.37528 b$ & $4.50333 \mathrm{a}$ & $0.43301 b$ & $0.20207 a$ \\
\hline & \multirow[t]{2}{*}{ Female } & Mean & 5.0000 & 1.2500 & 3.1000 & 22.1000 & 171.0000 & 31.8500 & 53.0400 \\
\hline & & $\mathrm{SE}$ & $0.08660 \mathrm{a}$ & $0.03464 b$ & $0.11547 \mathrm{a}$ & $0.34641 b$ & $3.46410 \mathrm{a}$ & $0.28868 \mathrm{a}, \mathrm{b}$ & $0.14434 a$ \\
\hline \multirow[t]{4}{*}{ Winter } & \multirow[t]{2}{*}{ Male } & Mean & 5.4000 & 1.3600 & 2.7000 & 23.8000 & 172.2100 & 30.0000 & 54.0100 \\
\hline & & SE & $0.20207 \mathrm{a}$ & $0.01443 \mathrm{a}$ & $0.17321 \mathrm{a}$ & $0.25981 \mathrm{a}$ & $4.99408 \mathrm{a}$ & $0.20207 \mathrm{a}$ & $0.25981 \mathrm{~b}$ \\
\hline & \multirow[t]{2}{*}{ Female } & Mean & 4.6000 & 1.1500 & 3.0000 & 20.7000 & 169.8000 & 31.1500 & 53.0100 \\
\hline & & $\mathrm{SE}$ & $0.23094 \mathrm{a}$ & $0.01155 \mathrm{a}$ & $0.28868 \mathrm{a}$ & $0.20207 \mathrm{a}$ & $4.33013 \mathrm{a}$ & $0.34641 \mathrm{a}$ & $0.20207 \mathrm{a}$ \\
\hline
\end{tabular}

Table-2 Analysis of one-way ANOVA on mean blood parameters by sex and seasons in C.catla

\begin{tabular}{|c|c|c|c|c|c|c|}
\hline Variables & Source & Sum of squares & $\rho g$ & Mean square & $\mathrm{g} / \mathrm{dl}$ & significance \\
\hline \multirow[t]{5}{*}{ Hemo } & Season & 28.588 & 4 & 7.147 & 90.813 & 0.000 \\
\hline & Sex & 8.619 & 1 & 8.619 & 109.516 & 0.000 \\
\hline & Season* sex & 0.472 & 4 & 0.118 & 1.499 & 0.240 \\
\hline & Error & 1.574 & 20 & 0.079 & & \\
\hline & Corrected total & 39.253 & 29 & & & \\
\hline \multirow[t]{5}{*}{$\mathrm{RBC}$} & Season & 0.827 & 4 & 0.207 & 165.444 & 0.000 \\
\hline & Sex & 0.324 & 1 & 0.324 & 259.584 & 0.000 \\
\hline & Season* sex & 0.125 & 4 & 0.031 & 25.044 & 0.000 \\
\hline & Error & 0.025 & 20 & 0.001 & & \\
\hline & Corrected total & 1.302 & 29 & & & \\
\hline \multirow[t]{5}{*}{ Leuco } & Season & 24.975 & 4 & 6.244 & 37.643 & 0.000 \\
\hline & Sex & 1.027 & 1 & 1.027 & 6.190 & 0.022 \\
\hline & Season* sex & 0.218 & 4 & 0.054 & 0.328 & 0.856 \\
\hline & Error & 3.317 & 20 & 0.166 & & \\
\hline & Corrected total & 29.537 & 29 & & & \\
\hline \multirow[t]{5}{*}{ Hemato } & Season & 238.554 & 4 & 56.639 & 360.463 & 0.000 \\
\hline & Sex & 202.644 & 1 & 202.644 & 1224.805 & 0.000 \\
\hline & Season* sex & 8.940 & 4 & 2.235 & 13.509 & 0.000 \\
\hline & Error & 3.309 & 20 & 0.165 & & 0.000 \\
\hline & Corrected total & 453.447 & 29 & & & \\
\hline \multirow[t]{4}{*}{$\mathrm{MCV}$} & Season & 303.813 & 4 & 75.953 & 2.044 & 0.127 \\
\hline & Sex & 11.532 & 1 & 11.532 & 0.310 & 0.584 \\
\hline & Season* sex & 4.671 & 4 & 1.168 & 0.031 & 0.998 \\
\hline & Error & 743.060 & 20 & 37.153 & & \\
\hline
\end{tabular}




\begin{tabular}{lllllll}
\multirow{3}{*}{ MCHC } & Corrected total & 1063.077 & 29 & & & \\
& Season & 6.169 & 4 & 1.542 & 6.114 & 0.022 \\
& Sex & 1.587 & 1 & 1.587 & 6.291 & 0.021 \\
& Season* sex & 2.335 & 4 & 0.584 & 2.314 & 0.093 \\
& Error & 5.046 & 20 & 0.252 & & \\
$\mathrm{MCH}$ & Corrected total & 15.138 & 29 & & & 0.000 \\
& Season & 35.394 & 4 & 8.849 & 65.744 & 0.006 \\
& Sex & 1.248 & 1 & 1.248 & 9.276 & 0.000 \\
& Season* sex & 6.716 & 4 & 1.679 & 12.475 & \\
\hline
\end{tabular}

\section{Hematocrit (PCV)}

Season wise PCV value was higher in summer and lower in winter season irrespective of the sexes of C.catla fish. As shown in Table-1, the PCV value ranged from $23.8 \%$ to $32.9 \%$ in male fish, where as for female fish it varied between $20.70 \%$ to $27.0 \%$. The mean value of the male and the female fish was $29.398 \%$ and $24.24 \%$ respectively, which indicates that male fish was higher than the female fish throughout the study period.

\section{Mean corpuscular volume}

MCV value was higher in summer for both sex and lower in the winter. The MCV value of male fish ranged between 172.10 and $179.90 \mathrm{fl}$ and for female fish 169.80 and 179.00fl (Table-1). There was no major difference in male and female fish.

\section{Mean corpuscular hemoglobin}

The value of MCH throughout the experimental period was found to be varied between 53.00 and $55.31 \mathrm{\rho g}$ in male fish and for female fish it was between 53.01 and $57.00 \mathrm{\rho g}$ (Table-1). The MCH value was higher in female fish $(54.452 \mathrm{\rho g})$ than that of male fish $(54.452 \mathrm{\rho g})$. In both the sexes, higher value was observed in rainy season and lower value in winter season.

\section{Mean corpuscular hemoglobin concentration}

The MCHC value ranged from $30.00 \%$ in male fish to $31.80 \%$ in male fish where as for female fish it was varied between $31.10 \%$ and $32.20 \%$ (Table-1). Higher value was observed in the rainy season and lower value in winter season in case of male fish, but for female fish it was in spring season. The annual mean value indicated as slightly higher in female fish (31.57\%) in comparison with male fish $(31.10 \%)$.

\section{Discussion}

In natural habitat, fish species are pact with different factors such as varied water qualities, pollution, malnutrition, infection and disease and can adapt themselves such environmental conditions by changing their physiological activities. Although all these above factors linked to fish health, it is essential to establish an identity the causes of disease in fish presents as a challenge for the researchers and farmers. Water quality is an important factor, which is an responsible for variation in fish hematology, since fish live in close association with their environment (Casillas and Smith).

Table-3 Corelation analysis of blood parameters by seasons in C.catla

\begin{tabular}{|c|c|c|c|c|c|c|c|c|}
\hline Season & Variable & Hemo & $\mathrm{RBC}$ & Leuco & Hemato & $\mathrm{MCV}$ & $\mathrm{MCHC}$ & $\mathrm{MCH}$ \\
\hline \multirow[t]{4}{*}{ Spring } & Hemo & 1 & $0.976^{* *}$ & -0.589 & $0.941 * *$ & 0.508 & $0.982 * *$ & -0.667 \\
\hline & $\mathrm{RBC}$ & $0.976 * *$ & 1 & -0.714 & $0.985 * *$ & 0.323 & $0.922 * *$ & -0.794 \\
\hline & Leuco & -0.589 & -0.714 & 1 & $-0.821 *$ & 0.375 & -0.426 & $0.988 * *$ \\
\hline & Hemato & $0.941 * *$ & $0.985 * *$ & $-0.821 *$ & 1 & 0.187 & $0.860^{*}$ & $-0.880 *$ \\
\hline \multirow[t]{3}{*}{ S } & MCV & 0.508 & 0.323 & 0.375 & 0.187 & 1 & 0.662 & 0.229 \\
\hline & $\mathrm{MCHC}$ & $0982 * *$ & $0.922 * *$ & 0.426 & $0.860 *$ & 0.662 & 1 & -0.514 \\
\hline & $\mathrm{MCH}$ & $-0.667-$ & 0.794 & $0.988 * *$ & $-0.880 *$ & 0.299 & -0.514 & 1 \\
\hline \multirow[t]{7}{*}{ Summer } & Hemo & 1 & $0.976^{* *}$ & -0.589 & $0.941 * *$ & 0.508 & $0.982 * *$ & -0.667 \\
\hline & $\mathrm{RBC}$ & $0.947 * *_{-}$ & 1 & 0.218 & 0.811 & 0.743 & 0.179 & -0.552 \\
\hline & Leuco & -0.061 & 0.218 & 1 & -0.339 & 0.791 & $0.992 * *$ & 0.794 \\
\hline & Hemato & $0.955^{* *}$ & 0.811 & -0.339 & 1 & 0.217 & -0.401 & -0.838 \\
\hline & MCV & 0.497 & 0.743 & 0.791 & 0.217 & 1 & 0.785 & 0.334 \\
\hline & $\mathrm{MCHC}$ & -0.118 & 0.179 & $0.992 * *$ & 0.401 & 0.785 & 1 & 0.835 \\
\hline & $\mathrm{MCH}$ & -0.644 & -0.382 & 0.794 & $-0.838 *$ & 0.334 & $0.835^{*}$ & 1 \\
\hline \multirow[t]{7}{*}{ Rainy } & Hemo & 1 & $0.997 * *$ & -0.234 & $0.971 * *$ & 0.325 & -0.082 & 0.047 \\
\hline & $\mathrm{RBC}$ & $0.997 * *$ & 1 & -0.154 & $0.947 * *$ & 0.396 & 0.000 & 0.123 \\
\hline & Leuco & -0.234 & -0.154 & 1 & -0.462 & 0.777 & $0.981 * *$ & $0.881 *$ \\
\hline & Hemato & $0.971 * *$ & $0.947 * *$ & -0.462 & 1 & 0.104 & -0.318 & -0.176 \\
\hline & $\mathrm{MCV}$ & 0.325 & 0.396 & 0.777 & 0.104 & 1 & $0.883^{*}$ & $0.960 * *$ \\
\hline & $\mathrm{MCHC}$ & -0.082 & 0.000 & $0.981 * *$ & -0.318 & $0.883 *$ & 1 & $0.951 * *$ \\
\hline & $\mathrm{MCH}$ & 0.047 & 0.123 & $0.881 *$ & -0.176 & $0.960 * *$ & $0.951 * *$ & 1 \\
\hline
\end{tabular}


Seasonal Variations in Certain Hematological Factors of Catla Catla (Hamilton 1822)

\begin{tabular}{|c|c|c|c|c|c|c|c|c|}
\hline \multirow[t]{7}{*}{ Autumn } & Hemo & 1 & $0.990 * *$ & -0.114 & $0.997 * *$ & 0.389 & -0.434 & 0.154 \\
\hline & $\mathrm{RBC}$ & 0.990 ** & 1 & -0.172 & $0.997 * *$ & 0.303 & -0.518 & 0.060 \\
\hline & Leuco & -0.114 & -0.172 & 1 & -0.158 & $0.844 *$ & $0.897 *$ & $0.924 * *$ \\
\hline & Hemato & $0.997 * *$ & $0.997 * *$ & -0.158 & 1 & 0.336 & -0.488 & 0.095 \\
\hline & $\mathrm{MCV}$ & 0.389 & 0.303 & $0.844 *$ & 0.336 & 1 & 0.658 & $0.969 * *$ \\
\hline & $\mathrm{MCHC}$ & -0.434 & -0.518 & $0.897 *$ & -0.488 & 0.658 & 1 & $0.822 *$ \\
\hline & $\mathrm{MCH}$ & 0.154 & 0.060 & $0.924 * *$ & 0.095 & $0.969 * *$ & $0.822 *$ & 1 \\
\hline \multirow[t]{7}{*}{ Winter } & Hemo & 1 & $0.885^{*}$ & 0.224 & $0.900 *$ & 0.735 & -0.309 & $0.991 * *$ \\
\hline & $\mathrm{RBC}$ & $0.885^{*}$ & 1 & -0.252 & $0.999 * *$ & 0.347 & -0.715 & $0.918^{* *}$ \\
\hline & Leuco & 0.224 & -0.252 & 1 & -0.221 & 0.781 & $0.856^{*}$ & 0.128 \\
\hline & Hemato & $0.900 *$ & $0.999 * *$ & -0.221 & 1 & 0.379 & -0.692 & $0.931 * *$ \\
\hline & $\mathrm{MCV}$ & 0.735 & 0.347 & 0.781 & 0.379 & 1 & 0.386 & 0.690 \\
\hline & $\mathrm{MCHC}$ & -0.309 & -0.715 & $0.856^{*}$ & -0.692 & 0.386 & 1 & -0.393 \\
\hline & $\mathrm{MCH}$ & $0.991 * *$ & $0.918 * *$ & 0.128 & $0.931 * *$ & 0.690 & -0.393 & \\
\hline
\end{tabular}

Table-4 Correlation analysis of blood parameters for male C.catla during study period.

\begin{tabular}{llllllll}
\hline & Hemo & RBC & Leuco & Hemato & MCV & MCHC & MCH \\
\hline Hemo & 1 & $0.861^{* *}$ & $0.961^{* *}$ & $0.960^{* *}$ & $0.558^{*}$ & $0.674^{* *}$ & 0.352 \\
RBC & $0.861^{* *}$ & 1 & $0.735^{* *}$ & $0.905^{* *}$ & 0.389 & $0.773^{* *}$ & 0.097 \\
Leuco & $0.961^{* *}$ & $0.735^{* *}$ & 1 & $0.881^{* *}$ & $0.628^{*}$ & $0.615^{*}$ & 0.353 \\
Hemato & $0.960^{* *}$ & $0.905^{* *}$ & $0.881^{* *}$ & 1 & 0.398 & 0.398 & 0.350 \\
MCV & $0.558^{*}$ & 0.389 & $0.628^{*}$ & 0.398 & 1 & 1 & 0.259 \\
MCHC & $0.674^{* *}$ & $0.773^{* *}$ & $0.615^{*}$ & $0.749^{* *}$ & $0.564 *$ & $0.564 *$ & 0.405 \\
MCH & 0.352 & 0.097 & 0.353 & 0.350 & 0.259 & 0.259 & 1
\end{tabular}

Table-5

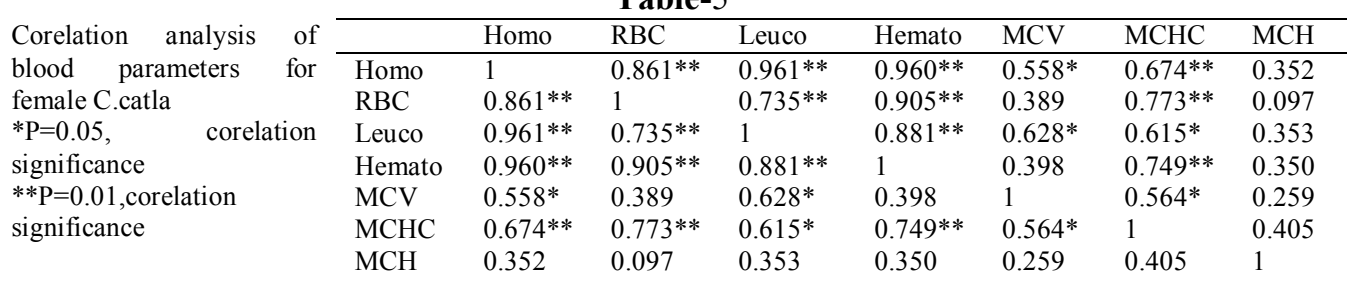

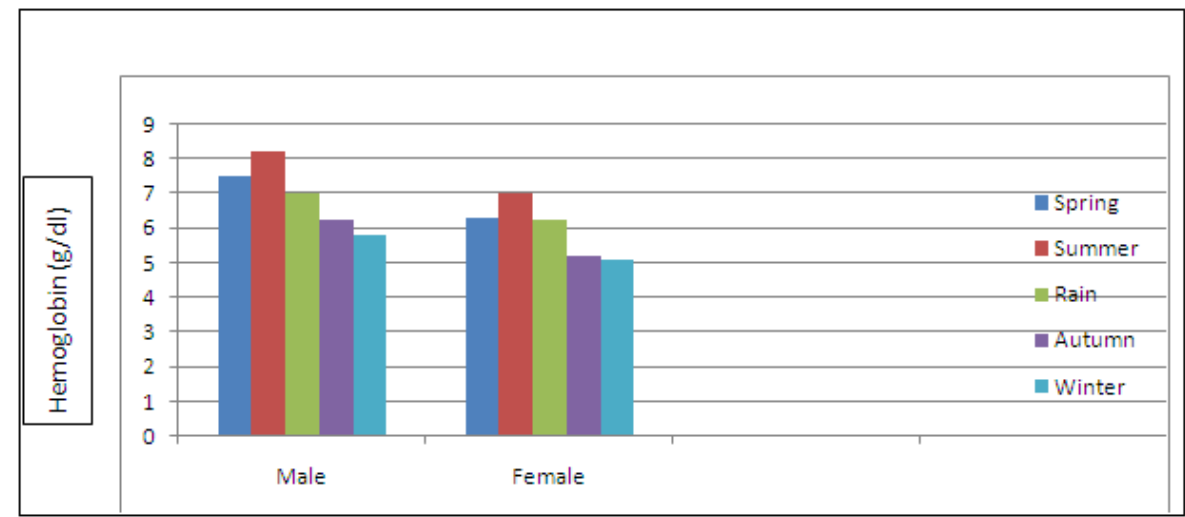

Fig. 1 Average concentration of blood $\mathrm{Hb}$ of $\mathrm{C}$. catla a between sexes.

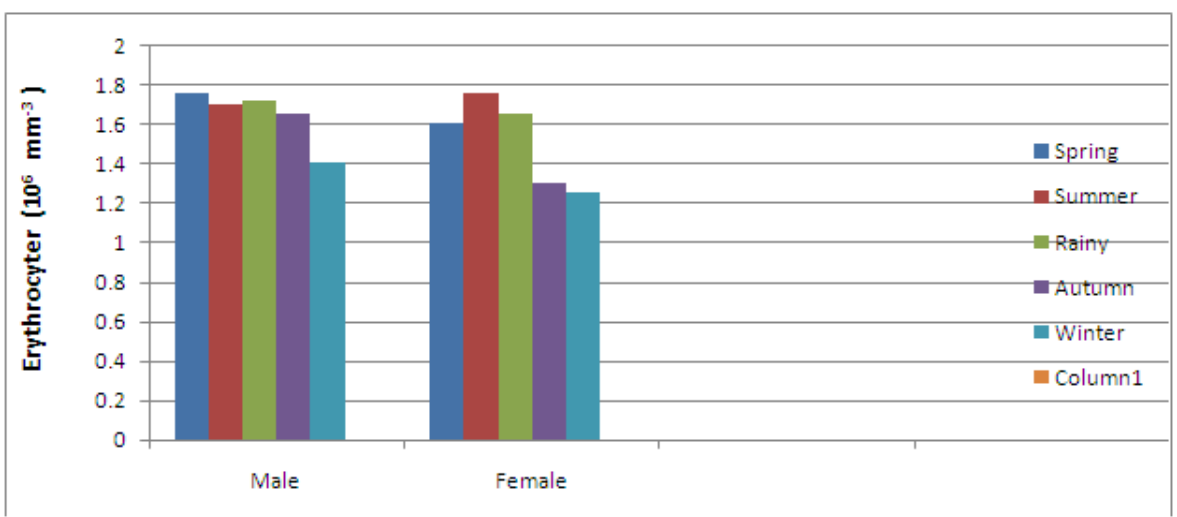

Fig.2 Average number of erythrocyte count of $\mathrm{C}$ catla a between sexes. 
Recently, Orun et al. (2003) described that fish hematology parameters could be affected by variations in water temperature and oxygen concentration. In this study, water quality was normal range without any interference with other external and environmental factors except rainy season (unpublished data).

There are abundant excellent references used as guides in the unusual fish health and incisive expert needs to use all available diagnostic skills to manage these cases. In this scenarios, the use of clinical pathology greatly enhances this endeavour. Among all the different parameters, hematology offers an easily collected diagnostic gizmo of fish pathology (Lehman and Sturenberg 1975; Hickey 1976). On the other hand, it is important to establish reference ranges for hematological parameters including the $\mathrm{RBC}$ and $\mathrm{WBC}$ numbers, cell proportions of leukocyte, amount of hemoglobin and the size of RBC and WBC. These are the most significant findings as regards to diagnosis of fish diseases, healtth monitoring and the direction of any ecological and geographical difference between the species. Many hematological reports are available in small and young Cyprinidae fishes by different researchers in different approaches, but the present work basically focused on reference ranges for hematological information in adult species of C.catla. The hematological parameters observed in this study showed marginal differences in comparision withthat of Clarias isheriensis i(KoriSiakpere 1985) and Clarias buthupogon (Kori-Siakpere and Egor 1997 ; Kori- Siakpere et al. 2005). Preston (1960) observed seasonal fluctuations in hematological parameters of fishes. Many publications reported that there are variations in blood indices values that can be attributed to manmy factors such as age , size of fish, nutrition state, season, spawning, sex and genetic variation. Das in 1965 discovered that the number of blood cells and hemoglobin concentration tends to increase with length and age. Hematocrit value for male fish was increased prior to time of sspawning (Poston 1966). The findings of the present study on blood indices of C.catla, which shows similar seasonal and sex variations, is discussed. Moreover, this study further attributes that during summer time because of high body metabolic rate due to high ambient temperature and reproductive activities, most of the hematological parameters shown higher value than other seasons. The lowest value, on the other hand, that happened during winter might be due to low ambient temperature and low metabolic rate. These results are supported by findings of Adebayo et al. (2007), Joshi (1989) and Orun et al. (2003). Many publications demonstrated that variation in hematocrit value and other hematological parameters between sexes and diversity might be due to higher metabolic rate of male compared to the female (raizada et al. 1983); Fourie and Hatting 1976). Finding of the present work also support this idea, which has been related to an increase in fish activity with increase in size. While considering the sex variations, many workers demonstrated that male fish attributes higher values in almost all hematological parameters except TLC in female fish (Cech and Wohlschlag 1981; Orun et al. 2003). The higher hematological values in favour of male fish may be attributed to physiologically activeness than the female fish. However, $\mathrm{MCHC}$ and $\mathrm{MCH}$ values did not show any marked difference between seasons and sexes in our results during the 2-year study period.

In conclusion, fish hematology is highly dependent on health, physiological process, habitat and the understanding of different environmental factors that govern reference ranges for fish. Although most of the wild fishes on a pond have been sampled, the small numbers in any specific fish populations limit the interpretation of the results and further validation is required. As the reproductive programs influence the fish physiology, more research will be necessary to determine the effects of microhabitat, environmental conditions, ambient temperature, nutritional status and possible seasonal fluctuations on the fish hematological parameters.

\section{Acknowledgement}

We are extremely grateful to the head of the Dept. of Zoology, Utkal University, Bhubaneswar, India for providing necessary facilities to carry out this work.

\section{References}

[1]. Adebayo OT, Fagbenro OA, Ajayi CB, Popoola OM(2007) Normal haematological profile of Parachanna obscura as a dignostic tool in aquaculture. Int. J.Zool Res 3:193-199

[2]. Anderson D, Klontz GW (1965) Basic hematology for the fish culturist, Ann North Fish cul Conf. 16:38-41

[3]. Anver CE (2004) Blood Chemistry (electrolytes, lipoprotein and enzymes) values of black scorpion fish (Scorpacnaporcus, 1758) in the Dardnelles Turkey J. Biol Sci 4:716-719

[4]. Bhaskar BR, Rao KS (1985). Some hematological parameters of tarpon, Megalops Cyprinoils (Broussenet) from Visakhapatnam harbor, Masty 11:63-69

[5]. Bhaskar BR, Rao KS (1990) Use of hematological parameters as diagnostic tools in determining the health of milk fish. Chanos chanos (Forskal), in brackish water culture. Aquacul Fish Mang 21:125-129

[6]. Casillas E, Smith LS (1977) Effect of stress on blood coagulation and hematology in rainbow torut (Salma grindneri). J.Fish Biol 10:481-491

[7]. Cech JJ, Wohlschlag DE (1981) Seasonal patterns of respiration, gill ventilation and hematological characteristic in the striped mullet, Mugil cephalus, BullMar Sci 31:112-119

[8]. Chakrabarti P, Banarjee V (1988) Effect of sublethal analysis of three organophosphores pesticide on the peripheral haemaogram of the fish, (Channa punclatus), Environ Ecol 6:151-158

[9]. Collazos ME, Ortega E, Barriga C, Rodrigeuez AB (1998). Seasonal variation in hematological parameters of male and female Tinca tinca, Mol Cell Biochem 183:165-168 
[10]. Dacie JV, Lewis SM (eds) (1975) Measurement and calculation of size of red cells, practical hematology, Churchill Livingstone, London, pp 40-43

[11]. Fourie FLR, Hatting J (1976). A seasonal study of hematology of carp, Cyprinus capria from a locality in the Transvaal, South Africa Zool. Afri2(1):75-80

[12]. Garcia MP, Echevarian G, Matrinez FJ, Zamora Z (1992) Influence of Blood Sample collection on the hematocrit value of two teleost rainbow trout (Oncahrhynclus bus mykiss) and European Sea bass (Dicentrachus has labrax L), Comp Bio chem Physical 101:733-736

[13]. Hesser EF (1960) Methods for routine on fish hematology. Prog Fish cult 22:164-171

[14]. Hickey CR (1982) Fish hematology, its uses and significance Game J 23(2):170-175

[15]. Hickey CR (1982) Comparative hematology of wild and captive Cunners, Trans Am Fish Soc 111:242-249

[16]. Iwama GK, Greer GL, Larkin DA (1976) Changes in some hematological characteristics of coho salmon (Oncorhyclouskisutch) in response

[17]. to acute exposure to dehydroabetric acid (DHAA) at different exercise levels J.Fish Res Bd can 33:285-289

[18]. Johnson DW (1968) Pesticides and fishes a review of selected literature, Trans Am fish Soc 97(4):398-424

[19]. Joshi PC (1989) seasonal changes in the blood parameters of a hillstream teleost, Channa gochua, Comp Physiol Ecol 14:71-73

[20]. Kori-Siakpere O (1985). Hematological characteristic of the African mudfish; Clarius bathupagon (Claridae). Bull Sci Ass Nig.21:177-185

[21]. Kori-Siakpere O, Ake JEG, Idoge E (2005). Hematological characteristicof the African Snakehead, Prachannaabscura. AFJ Biot 4 (6) $527-530$

[22]. Lavanya S, Ramesh M, Kavitha C, malarvizhi A (2011) Hematological, biochemiocal and inonregulatory response of Indian major carp Catla catla during chronic sublethal exposure to inorganic arsenicChemosphere 82(7):977-985

[23]. Lehman J, Sturenberg FJ (1975) Gewasser and Abwasser in Eme LimnologischeSchriflenrvihe, H.Kaltenmeier Sohne, Krefeld Huls, Germany (1975) Heft 55/56

[24]. Oluyemi KG, Adecprusi EA, Olanrewage J (2008). Basic hematological parameters in African cat fish, Clarias gariepinus(Burchell, 1822) FED ascribe acid supplemented diets Res J Ani Sci 2(1):17-21

[25]. Orun 1, Doruca M, Yazlak H (2003) Hematological parameters of three Cyprinid fish species; Onl J Biol. Sc. 3(3):320-328

[26]. Pal A, Parida SP, Swain MM (2008) Hematological and Plasma biochemistry in fan thooated lizard Psanmophilus blanfordanus (Sarita: Agamadie). Comp Clin Pathol. Doi:10-1007/s00580-011-1303-7

[27]. Poston 11A (1960) effects of sex and reproductive stage on haemoglobin levels in brown trout. Fish Res. Bull 29:28-29

[28]. Preston A (1960) Red blood values in the plaice (Pleuoronectes platessa L). J.Mar Biol 39:681-687

[29]. Raizada MN, Jain KK, Raizada S (1983) (1983) Monthly variations in the hematocrit values (PCV) in a teleost, Cirrhinusmrigala(Ham.) Comp Physiol 8(3):196-198

[30]. Siddique AQ, Naseem SM (1979) The hematology of Rohu, Labeorohita, S.Fish Biol 14:67-72

[31]. Svobodova Z, Pravoda D, Palackova J (1991) Unified methods of hematological examination of fish.Vodary, Czechoslovakia: Research unit of fish culture and hydrobiol, $31 \mathrm{pp}$

[32]. Tripathy G, Harsh S (2002) Fenvelerate.induced macromolecularchanges in the catfish, Clarias batraclus, J Boston Biol 23:143-146

[33]. Wedemeyer GA, Gould RW, Yasutake WT (1983) Some potential and limits of the leucocrit test as a fish health assessment method J. Fish Biol. 23:711-716 